Check for updates

Cite this: RSC Adv., 2020, 10, 818

\section{Sulphated alumina tungstic acid (SATA): a highly efficient and novel heterogeneous mesostructured catalyst for the synthesis of pyrazole carbonitrile derivatives and evaluation of green metrics $\dagger$}

\author{
Ryhan Abdullah Rather, Mohd Umar Khan and Zeba N. Siddiqui (D) * \\ A novel mesostructured catalyst sulphated alumina tungstic acid (SATA) has been prepared by an easy route. \\ Various techniques such as IR, XRD, SEM, EDX, TEM, TGA and BET were used to characterize the synthesized \\ catalyst. The catalytic activity of the meso material has been explored by synthesizing a series of new \\ pyrazole carbonitrile derivatives from aromatic aldehydes, ethylcyanoacetate, phenylhydrazine/hydrazine \\ hydrate in ethanol under reflux conditions. Furthermore, the "greenness" of this protocol when estimated \\ by green metrics, displayed satisfactory results. The protocol is free from column chromatography, and \\ toxic solvents and is more efficient as compared to reported ones.
}

Received 1st November 2019 Accepted 18th December 2019

DOI: $10.1039 / c 9 r a 09013 d$

rsc.li/rsc-advances tungstic acid include oxidation, ${ }^{23}$ hydroxylation, ${ }^{24}$ epoxidation ${ }^{25}$ and many other transformations. ${ }^{26-28}$ In spite of these advantageous properties and applications, tungstic acid suffer from severe drawbacks such as their deactivation during reaction due to coke formation on the surface and low surface area. ${ }^{29}$ This limits its applications in many reactions..$^{30}$ These drawbacks, however, can be removed by dispersing them on solid support materials with a high surface area. In this regard, mesoporous materials are good candidates as they possess unique structural features such as huge BET, large surface area, tunable pore diameter, flexibility to accommodate several functional groups and metals on to the surface. The introduction of mesoporous materials has brought tremendous economic and environmental revolution ${ }^{31}$ and plays a key role in catalysis ${ }^{32}$ at the industrial scale. Among mesoporous materials, mesoporous alumina is a good choice as it is cheap and easily available and also possesses beneficial properties such as high thermal stability, high purity, favourable bulk density, etc. ${ }^{33}$

In the present work, we have developed an easy route for the synthesis of mesoporous sulphated alumina tungstic acid and explored its catalytic activity by synthesizing a series of new pyrazole carbonitrile derivatives via multicomponent reaction. It is worthy to mention that pyrazole carbonitriles are interesting scaffolds due to their potential biological activities including anti-HIV ${ }^{34}$ antibacterial and antifungal ${ }^{35}$ anticancer $^{36}$ anti-depressant activities ${ }^{37}$ etc.

\section{Results and discussion}

The synthesis of catalyst sulphated alumina tungstic acid (SATA) is shown in Scheme $1 . \mathrm{H}^{+}$ion concentration of the catalyst was obtained as 0.44 meq. $\mathrm{g}^{-1}$ using back titration method.
Department of Chemistry, Aligarh Muslim University, Aligarh, 202002, India. E-mail: siddiqui_zeba@yahoo.co.in; zns.siddiqui@gmail.com

$\dagger$ Electronic supplementary information (ESI) available. See DOI: 10.1039/c9ra09013d 


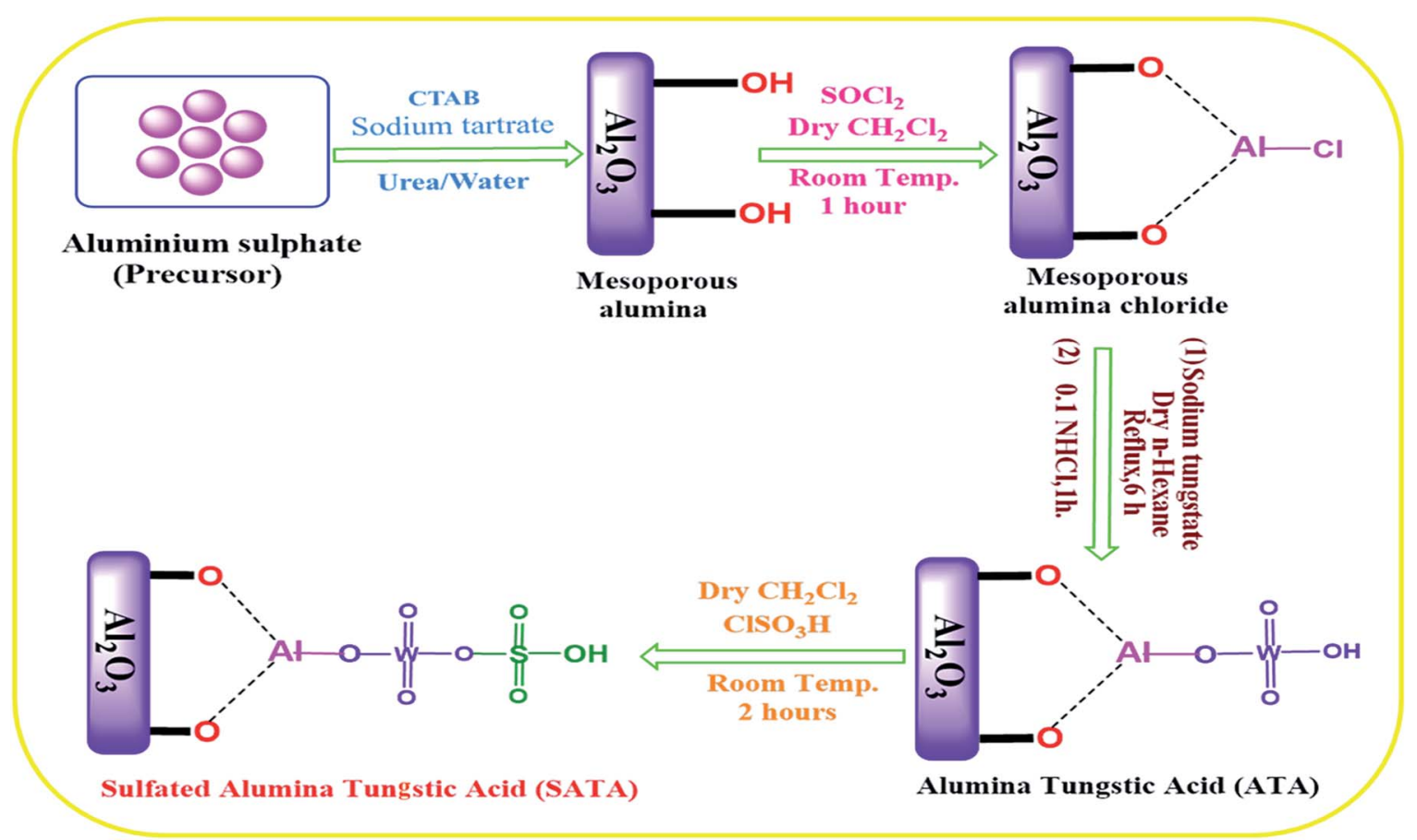

Scheme 1 Flow diagram depicting preparation of catalyst.

The IR spectrum (Fig. 1a), exhibited absorption peak at $3420 \mathrm{~cm}^{-1}$ due to surface OH groups. The absorption peaks between $510-1000 \mathrm{~cm}^{-1}$ were due to bending and stretching vibrations of $\mathrm{Al}-\mathrm{O}$ bond. ${ }^{38}$ Sulphated alumina tungstic acid (SATA) (Fig. 1b) showed bands at $1647 \mathrm{~cm}^{-1}$ due to $\mathrm{WO}_{4}{ }^{2-}$ group, $1130 \mathrm{~cm}^{-1}$ due to $\mathrm{SO}_{2}{ }^{2-}$ group and $600-700 \mathrm{~cm}^{-1}$ due to S-O bond.

In the XRD spectrum of catalyst sulphated alumina tungstic acid (SATA) (Fig. 2a) peaks at $29.89^{\circ}, 44.96^{\circ}, 59.95^{\circ}, 64.99^{\circ}$, $69.92^{\circ}$ corresponded to $\gamma-\mathrm{Al}_{2} \mathrm{O}_{3}$ and peaks at $24.98^{\circ}, 34.95^{\circ}$, $39.98^{\circ}, 50.45^{\circ}, 54.89^{\circ}$ were due to different phases of $\alpha-\mathrm{Al}_{2} \mathrm{O}_{3}{ }^{39}$ The XRD spectrum of SATA exhibited an additional peak at $22^{\circ}$ (Fig. 2b) due to $\mathrm{WO}_{4}$ group. ${ }^{40}$ Some insignificant changes in the nature of peaks were observed because of bonded sulfonic acid groups on the alumina surface.

SEM images of synthesized mesoporous alumina (Fig. 3a) showed the spherical shape of the synthesized mesoporous $\mathrm{Al}_{2} \mathrm{O}_{3}$ particles. After functionalization, there were insignificant

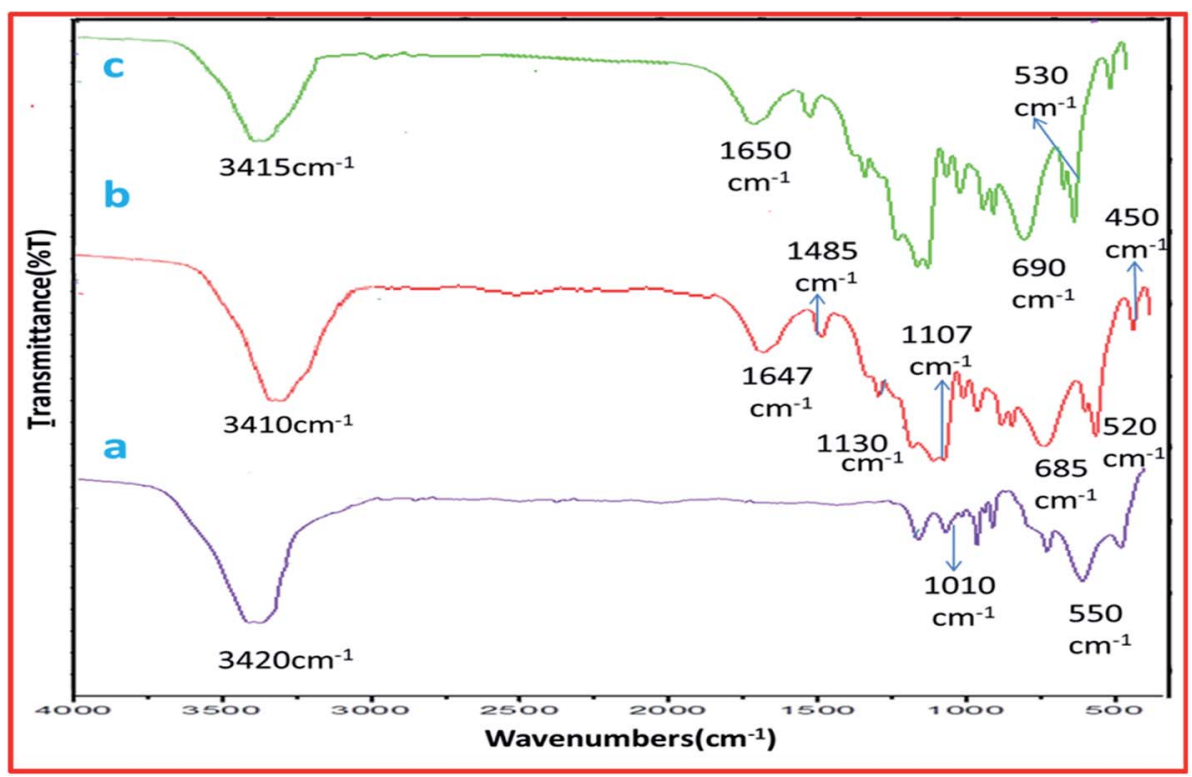

Fig. 1 FT-IR spectra of (a) mesoporous alumina (b) fresh SATA and (c) recycled SATA. 


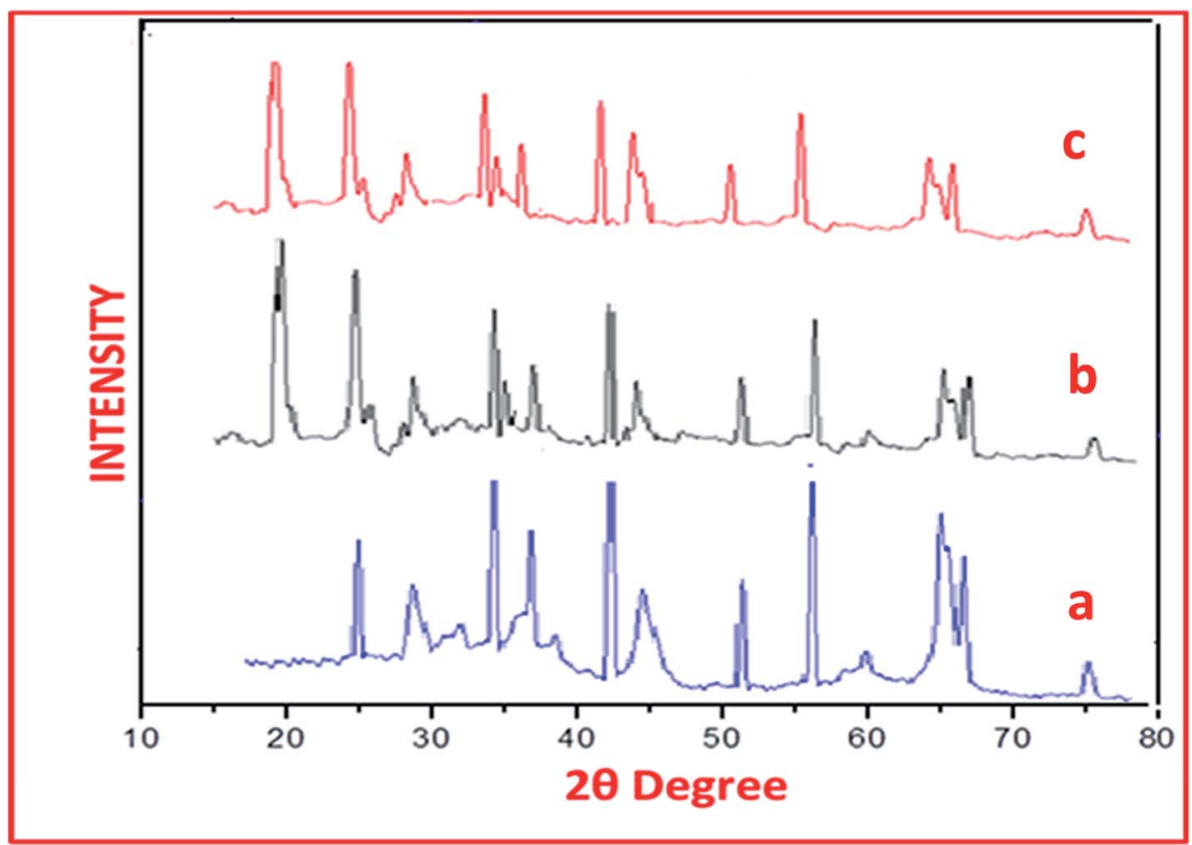

Fig. 2 XRD spectra of (a) mesoporous alumina, (b) fresh SATA and (c) recycled SATA.

morphological changes in the synthesized material sulphated alumina tungstic acid (Fig. 3b). The EDX analysis (Fig. 3c) of the catalyst showed the presence of constituent elements $\mathrm{W}, \mathrm{Al}, \mathrm{O}$, and S. TEM image (Fig. 4A) of the catalyst (SATA) exhibited a wormhole-like porous structure. Furthermore the TEM image of the recycled catalyst (Fig. 4B) showed same morphology indicating that the structure of the synthesized catalyst was not disturbed.
The surface area of catalyst (SATA) was found to be $298.54 \mathrm{~m}^{2} \mathrm{~g}^{-1}$ (Fig. 5) which was slightly lower than the mesoporous alumina $\left(308 \mathrm{~m}^{2} \mathrm{~g}^{-1}\right){ }^{41}$ The decrease in the surface area could be due to functionalization of mesoporous alumina.

The TGA curve (Fig. 6) showed a weight loss of $18.8 \%$ up to $114{ }^{\circ} \mathrm{C}$ due to removal of water molecules trapped in alumina framework. Another weight loss of $6.58 \%$ at $303{ }^{\circ} \mathrm{C}$ can be

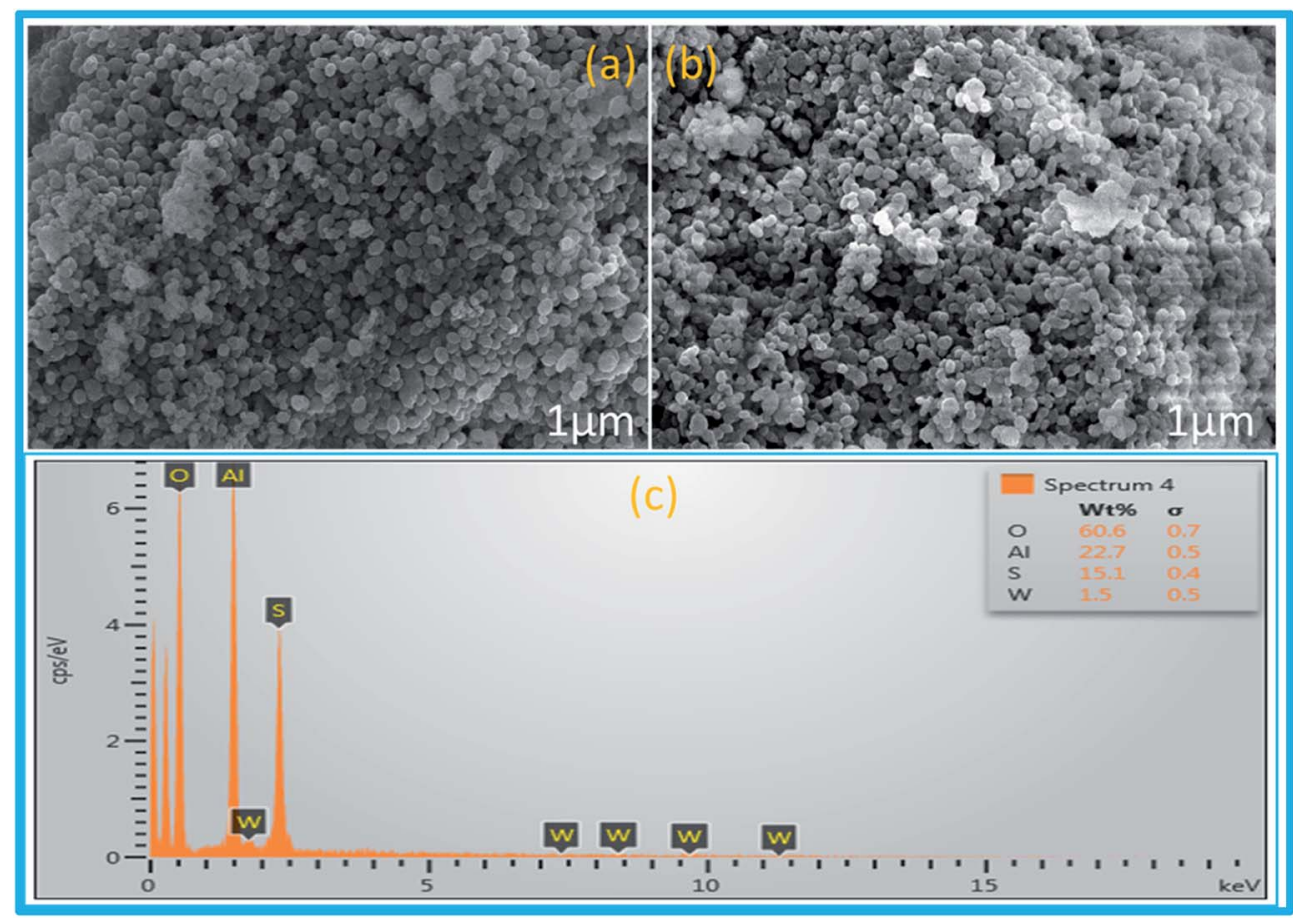

Fig. 3 SEM images of (a) freshly synthesized mesoporous $\mathrm{Al}_{2} \mathrm{O}_{3}$, (b) SATA and (c) EDX analysis of SATA. 


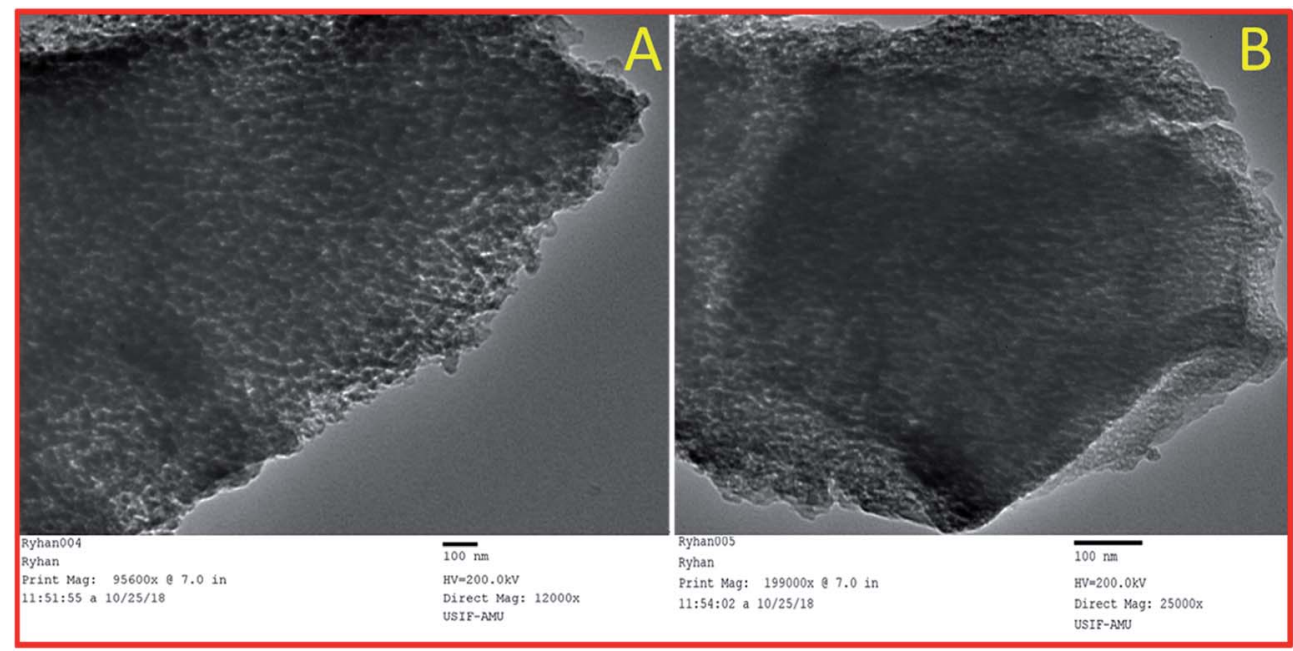

Fig. 4 TEM images of (A) fresh catalyst SATA and (B) recycled catalyst SATA.

attributed to the decomposition of bonded sulfonic acid groups from the surface of mesoporous alumina.

\section{Optimization of reaction conditions}

To find out suitable reaction conditions using SATA for the synthesis of pyrazole carbonitriles, various parameters such as different catalysts/solvents, catalyst loading, temperature etc. were tried to get maximum yield of product (4a). To find suitable catalyst for our reaction we first tried the reaction in the absence of any catalyst. The reaction failed to produce any yield indicating the need of a catalyst (Table 1 , entry 1 ). Then effect of the different sulphuric acid based catalysts under reflux condition was examined. Among them, $\mathrm{CH}_{3} \mathrm{COOH}$ and $\mathrm{H}_{2} \mathrm{SO}_{4}$ catalyzed reactions did not give satisfactory result (Table 1, entries 2 and 3). Among silica, alumina and zirconia-based sulphuric acids, $\mathrm{H}_{2} \mathrm{SO}_{4}$-alumina afforded slightly better product yield (Table 1, entry 6). Similarly, PEG and xanthan like supported sulphuric acid organic polymers also gave unsatisfactory yields (Table 1,

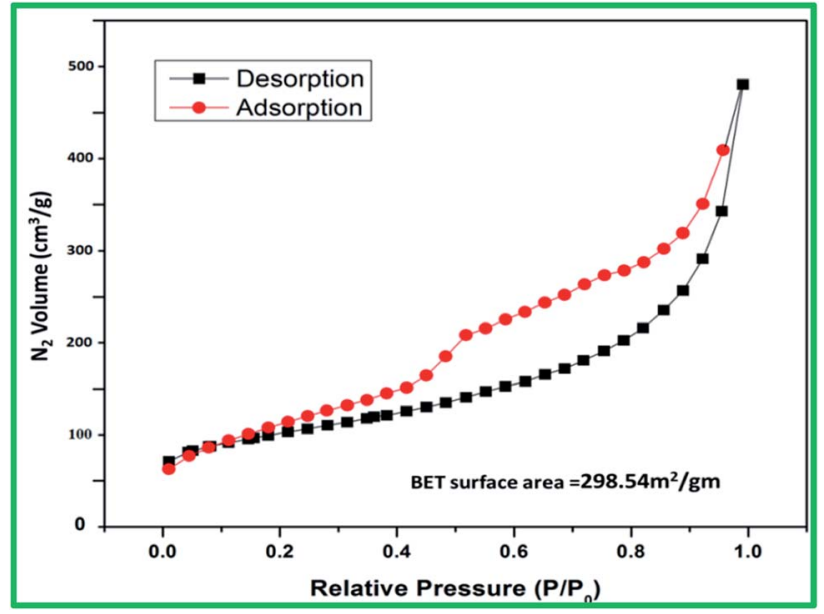

Fig. 5 BET analysis of synthesized catalyst SATA. entries 8 and 9). In the presence of sodium tungstate, the product yield was slightly increased but took a longer time (Table 1, entry 10). The use of alumina tungstic acid (ATA) showed better results (Table 1, entry 11). However, the best results were obtained with sulphated ATA (SATA) affording 94\% product yield in 15 min (Table 1, entry 12). Then our study focused on the development of the optimal reaction conditions for this transformation, which included solvent screening and influence of the catalyst amount. Several organic solvents like isopropanol, acetonitrile, methanol, hexane, toluene, and ethane diol when tested, (Table 1, entries 19-24), ethanol was found as a preferred solvent for maximum conversion of substrate into products (94\%) in the minimum time period (15 min) (Table 1, entry 12). To find the optimized amount of the catalyst, the reaction was carried out by varying the amount of the catalyst on the model reaction (Table 2). It was found that

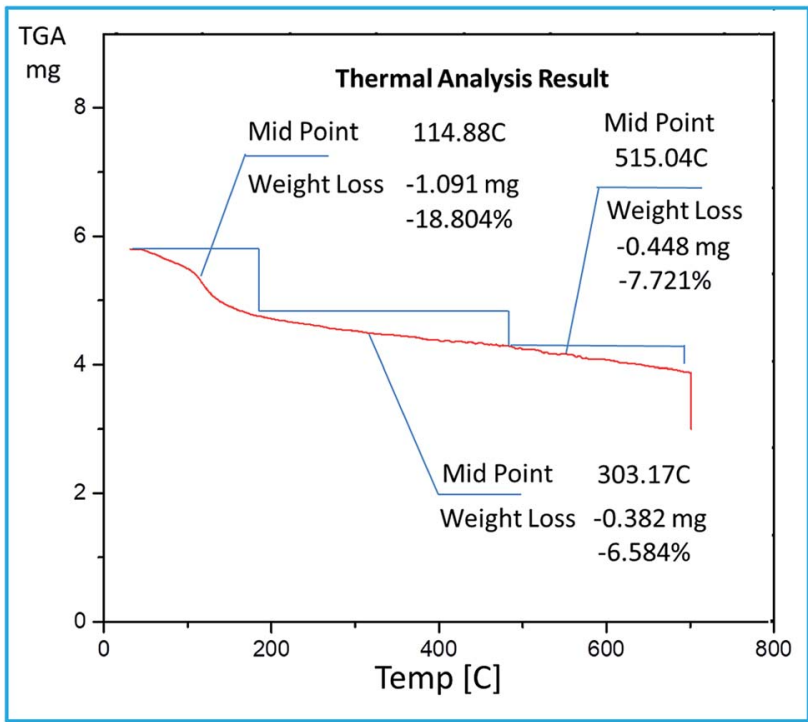

Fig. 6 TGA curve of synthesized catalyst SATA. 
Table 1 Effect of various reaction media for the model reaction ${ }^{a}$

\begin{tabular}{|c|c|c|c|c|c|}
\hline Entry & Catalyst & Condition & Time $^{b}$ & Yield $^{c}$ & References $^{d}$ \\
\hline 1 & - & Ethanol/reflux & $18 \mathrm{~h}$ & - & \\
\hline 2 & AcOH (10 mol\%) & Ethanol/reflux & $9 \mathrm{~h}$ & 56 & 42 \\
\hline 4 & $\mathrm{H}_{2} \mathrm{SO}_{4}-\mathrm{SiO}_{2}(200 \mathrm{mg})$ & Ethanol/reflux & $5 \mathrm{~h}$ & 62 & 44 \\
\hline 5 & $\mathrm{H}_{2} \mathrm{SO}_{4}-\mathrm{ZrO}_{2}(200 \mathrm{mg})$ & Ethanol/reflux & $6 \mathrm{~h}$ & 58 & 45 \\
\hline 6 & $\mathrm{H}_{2} \mathrm{SO}_{4}-\mathrm{Al}_{2} \mathrm{O}_{3}(200 \mathrm{mg})$ & Ethanol/reflux & $3.5 \mathrm{~h}$ & 70 & 46 \\
\hline 9 & $\mathrm{H}_{2} \mathrm{SO}_{4}-\mathrm{PEG}(200 \mathrm{mg})$ & Ethanol/reflux & $5.2 \mathrm{~h}$ & 64 & 49 \\
\hline 10 & $\mathrm{Na}_{2} \mathrm{WO}_{3}(10 \mathrm{~mol} \%)$ & Ethanol/reflux & $4 \mathrm{~h}$ & 68 & 50 \\
\hline 11 & ATA $(200 \mathrm{mg})$ & Ethanol/reflux & $92 \mathrm{~min}$ & 76 & Present work \\
\hline 12 & ATA-OSO $_{3} \mathrm{H}(\mathrm{SATA})(100 \mathrm{mg})$ & Ethanol/reflux & $15 \mathrm{~min}$ & 94 & Present work \\
\hline 13 & $\mathrm{FeCl}_{3}(10 \mathrm{~mol} \%)$ & Ethanol/reflux & $6.2 \mathrm{~h}$ & 42 & 51 \\
\hline 14 & $\mathrm{ZnCl}_{2}(10 \mathrm{~mol} \%)$ & Ethanol/reflux & $6 \mathrm{~h}$ & 40 & 52 \\
\hline 19 & SATA (100 mg) & Methanol & $7 \mathrm{~h}$ & 78 & \\
\hline 20 & SATA $(100 \mathrm{mg})$ & Isopropanol & $7.2 \mathrm{~h}$ & 72 & \\
\hline 21 & SATA (100 mg) & Acetonitrile & $7 \mathrm{~h}$ & 56 & \\
\hline 22 & SATA (100 mg) & Hexane & $8 \mathrm{~h}$ & 52 & \\
\hline 23 & SATA $(100 \mathrm{mg})$ & Toluene & $7.2 \mathrm{~h}$ & 56 & \\
\hline 24 & SATA (100 mg) & Ethylene glycol & $7 \mathrm{~h}$ & 48 & \\
\hline
\end{tabular}

${ }^{a}$ Reaction conditions: 4-chlorobenzaldehyde $1 \mathrm{a}(1 \mathrm{mmol})$, ethyl cyanoacetate $2(1 \mathrm{mmol})$, phenylhydrazine $3 \mathrm{a}(1 \mathrm{mmol})$, in presence of different reaction media. ${ }^{b}$ Reaction progress monitored by TLC. ${ }^{c}$ Isolated yield. ${ }^{d}$ References of the catalysts used before for the similar kind of reactions under different reaction conditions.

the conversion of the pyrazole carbonitrile derivative increased linearly with increase in the amount of catalyst from 50-100 mg (Table 2, entry 1-3). With further increase in the amount of catalyst, the product yield was not increased, so $100 \mathrm{mg}$ of the catalyst was found to be the optimum amount of catalyst for the desired reaction. The temperature effect played a vital role in the synthesis of pyrazole carbonitriles. The reaction was unsuccessful at room temperature while increasing it upto $80^{\circ} \mathrm{C}$ product formation also increased linearly and completed at $80{ }^{\circ} \mathrm{C}$ (Table 3). As indicated in Table 3 , the effect of increasing temperature (from 25 to $80{ }^{\circ} \mathrm{C}$ ) is directly related to the improved yield of the product. Upon increasing the temperature further, the reaction afforded lesser yield of

Table 2 Effect of catalyst loading on the model reaction ${ }^{a}$

\begin{tabular}{llll}
\hline Entry $^{a}$ & $\begin{array}{l}\text { Catalyst loading } \\
(\mathrm{mg})\end{array}$ & Time $^{b}(\mathrm{~min})$ & Yield $^{c}(\%)$ \\
\hline 1 & 30 & 52 & 70 \\
2 & 50 & 45 & 78 \\
3 & 100 & 15 & 94 \\
4 & 150 & 15 & 88 \\
5 & 200 & 15 & 88
\end{tabular}

${ }^{a}$ Reaction conditions: 4-chlorobenzaldehyde $1 \mathrm{a}$ (1 mmol), ethyl cyanoacetate $2(1 \mathrm{mmol})$, phenylhydrazine $3 \mathrm{a}(1 \mathrm{mmol})$, in presence of different amounts of SATA in ethanol under reflux condition.

${ }^{b}$ Reaction progress monitored by TLC. ${ }^{c}$ Isolated yield. product. Thus, $80{ }^{\circ} \mathrm{C}$ was found to be the optimum temperature for the reaction.

In the light of green chemistry, it was vital to certify our procedure as eco-friendly, which was accomplished in terms of atom economy (AE), reaction mass efficiency (RME), overall efficiency (OE), carbon efficiency (CE), process mass intensity (PMI), E-factor and solvent intensity (SI).$^{55-58}$ Details of reactants and products used for metric calculations are given in ESI. $\uparrow$ The calculated values for AE (76-83\%), OE (91-94\%), CE (83-89\%), $E$-factor (19-12), SI (19-12) and PMI (20-13) are summarized in (Table 4) which endorse this presented method as green and sustainable.

Table 3 Effect of temperature on model reaction ${ }^{a}$

\begin{tabular}{llll}
\hline Entry & $\begin{array}{l}\text { Temperature } \\
\left({ }^{\circ} \mathrm{C}\right)\end{array}$ & Time $^{b}$ & Yield $^{c}(\%)$ \\
\hline 1 & 25 & $24 \mathrm{~h}$ & No reaction \\
2 & 45 & $1.5 \mathrm{~h}$ & 40 \\
3 & 65 & $60 \mathrm{~min}$ & 75 \\
4 & 75 & $45 \mathrm{~min}$ & 82 \\
5 & 80 & $15 \mathrm{~min}$ & 94 \\
6 & 100 & $24 \mathrm{~min}$ & 90
\end{tabular}

${ }^{a}$ Reaction conditions: 4-chlorobenzaldehyde $1 \mathrm{a}$ (1 mmol), ethyl cyanoacetate $2(1 \mathrm{mmol})$, phenylhydrazine $3 \mathrm{a}(1 \mathrm{mmol})$, in presence of SATA $(100 \mathrm{mg})$ in $5 \mathrm{~mL}$ ethanol/reflux. ${ }^{b}$ Reaction progress monitored by TLC. ${ }^{c}$ Isolated yield. 
Table 4 Summary of green metrics calculations of the synthesized compounds $(4 a-l)$

\begin{tabular}{|c|c|c|c|c|c|c|c|c|}
\hline Entry & $\begin{array}{l}\% \\
\text { yield }\end{array}$ & $\% \mathrm{AE}^{a}$ & $\% \mathrm{CE}^{b}$ & $\% \mathrm{RME}^{c}$ & $\% \mathrm{OE}^{d}$ & $\mathrm{PMI}^{e}$ & $\mathrm{SI}^{f}$ & $E$-factor ${ }^{g}$ \\
\hline $4 a$ & 94 & 81.73 & 88.88 & 76.84 & 94.01 & 15.47 & 14.17 & 14.47 \\
\hline $4 b$ & 94 & 82.25 & 88.88 & 77.41 & 94.11 & 14.97 & 13.68 & 13.97 \\
\hline $4 c$ & 94 & 82.25 & 88.88 & 77.41 & 94.11 & 14.97 & 13.68 & 13.97 \\
\hline 4d & 92 & 81.73 & 88.88 & 75.17 & 91.97 & 15.81 & 14.48 & 14.81 \\
\hline $4 e$ & 94 & 83.73 & 88.88 & 78.76 & 94.06 & 13.58 & 12.31 & 12.58 \\
\hline 4f & 92 & 81.50 & 89.47 & 74.90 & 91.90 & 16.03 & 14.70 & 15.03 \\
\hline $4 \mathrm{~g}$ & 94 & 78.86 & 83.33 & 72.25 & 94.00 & 20.46 & 19.08 & 19.46 \\
\hline $4 h$ & 92 & 77.69 & 83.33 & 71.47 & 91.99 & 19.98 & 18.58 & 18.98 \\
\hline $4 i$ & 94 & 77.69 & 83.33 & 73.02 & 93.98 & 19.57 & 18.21 & 18.57 \\
\hline $4 j$ & 92 & 76.86 & 83.75 & 70.71 & 91.99 & 20.91 & 19.50 & 19.91 \\
\hline $4 k$ & 92 & 89.13 & 83.33 & 82.01 & 92.01 & 17.43 & 16.21 & 16.43 \\
\hline 41 & 94 & 76.50 & 84.61 & 71.91 & 94.00 & 20.86 & 19.47 & 19.86 \\
\hline
\end{tabular}

\section{Catalytic reaction}

After optimizing the reaction conditions, a variety of pyrazole carbonitriles were synthesized (Table 5) (Scheme 2). The results indicated that reaction proceeded smoothly in the presence of a catalyst (SATA) giving an excellent yield of products successfully within a shorter period of time.

In order to demonstrate the advantage of our protocol, a comparison with reported available protocols in the literature was done (Table 6). In comparison to reported procedures, the present protocol proved competent, environmentally benign and practically more sound (Table 6). Moreover, catalyst can be easily separated at the end of reaction and has shown good reusability.

\section{Reusability and heterogenity of the catalyst}

The recycling experiments were performed to explore the recyclability level of our catalytic scheme. The recyclability level was studied for the heterogeneous nature of the catalyst (Fig. 7). The recovered catalyst catalysed the formation of $\mathbf{4 a}$ successfully for five consecutive cycles with good activity. The morphology of the recovered catalyst was almost unchanged as shown by XRD and TEM analysis (Fig. 2c and $4 \mathrm{~b}$ ) respectively. Furthermore, to figure out the heterogeneity of the catalyst sulphated alumina tungstic acid (SATA), hot filtration test was accomplished. The model reaction containing 4-chlorobenzaldehyde (1a), ethyl cyanoacetate (2), phenylhydrazine (3a) and (SATA) (100 mg) in ethanol was refluxed for $13 \mathrm{~min}$ and filtered off while hot. Taking this filtrate as reaction mixture, the reaction was further continued under similar reaction conditions for $30 \mathrm{~min}$ and it was found that the reaction could not proceed further. Therefore, it was concluded that the catalyst was heterogeneous in nature.

\section{Conclusion}

Herein, a good catalytic system based on mesoporous alumina was synthesized. The heterogeneous catalyst displayed excellent activity for the synthesis of pyrazole carbonitriles. All the substrates could be easily converted to products with high yield. The distinguishing features of this method included easy separation of the catalyst, mild reaction conditions, enhanced reaction rates, cleaner reaction profiles, and easy product separation procedures, which make this method attractive. Furthermore, the method described produced negligible waste, with good to excellent values of green chemistry metrics (AE, CE, RME, OE, PMI, SI, and E-factor), and showed standard choice in this framework.

\section{Experimental aspect}

\section{Preparation of mesoporous alumina $\left(\mathrm{Al}_{2} \mathrm{O}_{3}\right)$ and alumina tungstic acid (ATA)}

Mesoporous alumina was synthesized according to reported procedure $^{64}$ with slight modifications. Cetrimonium bromide (CTAB) $(0.2 \mathrm{mmol})$, aluminium sulphate $\left(\mathrm{Al}_{2}(\mathrm{SO} 4)_{3} \cdot 18 \mathrm{H}_{2} \mathrm{O}\right)$ $(1 \mathrm{mmol})$, urea $\left(\mathrm{CO}\left(\mathrm{NH}_{2}\right)_{2}\right)(4 \mathrm{mmol})$, and sodium tartrate $\left(\mathrm{C}_{4} \mathrm{H}_{4} \mathrm{O}_{6} \mathrm{Na}_{2}\right)(0.7 \mathrm{mmol})$ were suspended in demineralized water for about $0.5 \mathrm{~h}$ until complete dissolution. The solution was then kept in an autoclave with Teflon lining with maintained temperature at $165^{\circ} \mathrm{C}$ for $8 \mathrm{~h}$. The white precipitate as formed, after allowing autoclave to cool was collected, washed carefully with distilled water, dried at $80{ }^{\circ} \mathrm{C}$ for $12 \mathrm{~h}$ and finally calcined at $550{ }^{\circ} \mathrm{C}$ for $3 \mathrm{~h}$ to get rid of the impurities.

\section{Preparation of alumina tungstic acid (ATA)}

Dropwise addition of thionyl chloride $\left(\mathrm{SOCl}_{2} 20 \mathrm{~g}\right)$ to synthesized mesoporous alumina $(20 \mathrm{~g})$ in dry $\mathrm{CH}_{2} \mathrm{Cl}_{2}(50 \mathrm{~mL})$ at ambient temperature with constant stirring was performed. $\mathrm{HCl}$ and $\mathrm{SO}_{2}$ gases were evolved and reaction was allowed to proceed for another $1 \mathrm{~h}$. After that $\mathrm{CH}_{2} \mathrm{Cl}_{2}$ (solvent) was removed from the reaction mixture under suction to obtain alumina chloride. In next step mesoporous $\mathrm{AlCl}_{3}(6.00 \mathrm{~g})$ as formed and $\mathrm{Na}_{2} \mathrm{WO}_{4}$ $(7.03 \mathrm{~g})$ were taken in solvent $n$-hexane $(10 \mathrm{~mL})$ and refluxed with stirring for $6 \mathrm{~h}$. The solid as formed was filtered out from reaction mixture, washed with water, dried and stirred for another $1 \mathrm{~h}$ with $0.1 \mathrm{~N} \mathrm{HCl}(40 \mathrm{~mL})$ (Scheme 1). Finally, the solid was removed from the reaction mixture by filtration, washed several times with distilled water, and dried to obtain alumina tungstic acid (ATA).

\section{Preparation of sulphated alumina tungstic acid (SATA)}

Alumina tungstic acid (ATA) (2.5 g) was taken in a flat bottomed suction flask equipped with a dropping funnel, added $\mathrm{CH}_{2} \mathrm{Cl}_{2}$ (dry, $0.075 \mathrm{~L}$ ) and stirred for $10 \mathrm{~min}$. To the above reaction mixture, added dropwise chloro-sulfonic acid $(1.75 \mathrm{~mL})$ during 30 min. Upon complete addition, stirring of the reaction mixture was continued upto $90 \mathrm{~min}$. $\mathrm{HCl}$ was removed under reduced pressure. Solid was filtered and thoroughly washed 
Table 5 Synthesis of pyrazole carbonitrile derivatives in presence of SATA under reflux conditions ${ }^{a}$

1<smiles>O=Cc1ccc(Cl)cc1</smiles>

1a<smiles>O=Cc1cccc([N+](=O)[O-])c1</smiles><smiles>O=Cc1ccc([N+](=O)[O-])cc1</smiles>

1c<smiles>O=Cc1cccc(Cl)c1</smiles><smiles>O=Cc1ccc(Br)cc1</smiles>

1e<smiles>COc1ccc(C=O)cc1</smiles>

$1 f$<smiles>N#Cc1c(-c2ccc(Cl)cc2)n(-c2ccccc2)[nH]c1=O</smiles><smiles>CNNc1ccccc1</smiles>

$4 b$<smiles>N#Cc1c(-c2ccc([N+](=O)[O-])cc2)n(-c2ccccc2)[nH]c1=O</smiles>

4c<smiles>N#Cc1c(-c2cccc(Cl)c2)n(-c2ccccc2)[nH]c1=O</smiles>

16

92<smiles>N#Cc1c(-c2ccc(Br)cc2)n(-c2ccccc2)[nH]c1=O</smiles><smiles>COc1ccc(-c2c(C#N)c(=O)[nH]n2-c2ccccc2)cc1</smiles> 
Table 5 (Contd.)

\begin{tabular}{llll}
\hline Entry & $\mathbf{1 a}-\mathbf{f}$ & Products & Time $^{b}(\mathrm{~min})$
\end{tabular}

7<smiles>O=Cc1ccc(Cl)cc1</smiles>

$1 a$<smiles>O=Cc1cccc([N+](=O)[O-])c1</smiles>

$1 b$<smiles>O=Cc1ccc([N+](=O)[O-])cc1</smiles>

1c<smiles>O=Cc1cccc(Cl)c1</smiles><smiles>O=Cc1ccc(Br)cc1</smiles>

$1 \mathrm{e}$<smiles>COc1ccc(C=O)cc1</smiles>

$1 f$<smiles>N#Cc1c(-c2ccc(Cl)cc2)[nH][nH]c1=O</smiles>

$4 \mathrm{~g}$<smiles>N#Cc1c(-c2cccc([N+](=O)[O-])c2)[nH][nH]c1=O</smiles><smiles>N#Cc1c(-c2ccc([N+](=O)[O-])cc2)[nH][nH]c1=O</smiles>

15

94

$4 i$<smiles>N#Cc1c(-c2cccc(Cl)c2)[nH][nH]c1=O</smiles>

4j<smiles>N#Cc1c(-c2ccc(Br)cc2)[nH][nH]c1=O</smiles>

4k<smiles>COc1ccc(-c2[nH][nH]c(=O)c2C#N)cc1</smiles>

41
16

92

15

92

94

\footnotetext{
${ }^{a}$ Reaction of aldehydes (1a-f) $(1 \mathrm{mmol})$, ethylcyanoacetate $(2)(1 \mathrm{mmol})$ and hydrazines (3a/3b) in presence of SATA $(100 \mathrm{mg})$ in $5 \mathrm{~mL}$ ethanol/reflux.

${ }^{b}$ Reaction progress was monitored by TLC. ${ }^{c}$ Isolated yield.
} 


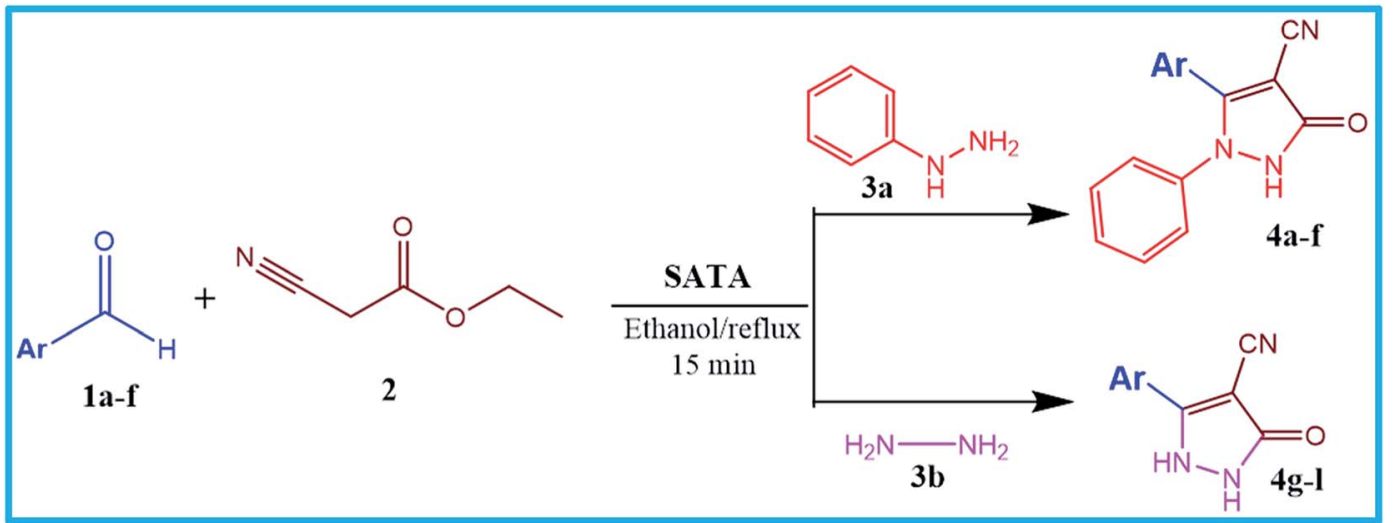

Scheme 2 General scheme for the formation of pyrazole carbonitrile derivatives.

Table 6 Comparison of efficiency of sulphated alumina tungstic acid (SATA) with reported methods

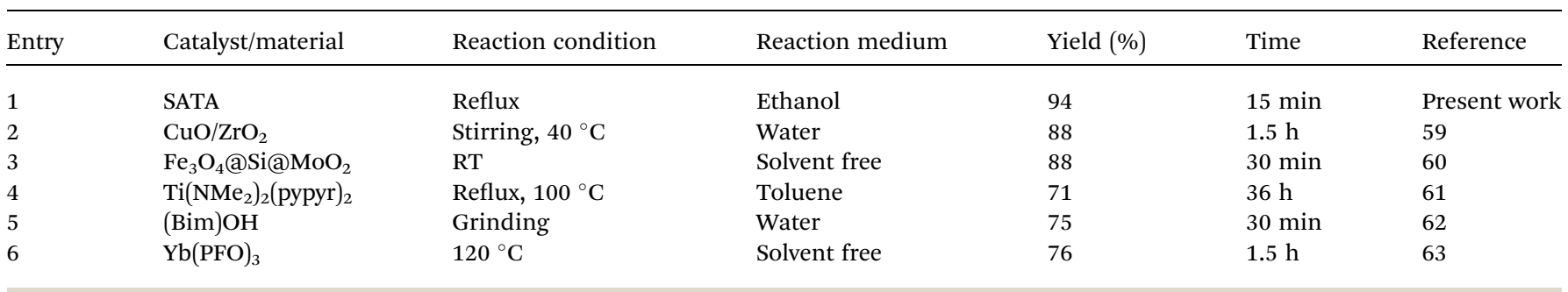

using $\mathrm{CH}_{2} \mathrm{Cl}_{2}$ as solvent and dried at $120{ }^{\circ} \mathrm{C}$ for $3 \mathrm{~h}$ to afford sulphated alumina tungstic acid (SATA).

\section{General procedure for synthesis of pyrazole carbonitrile} derivatives

Equimolar quantity of aldehyde (1a-e) ethyl cyanoacetate (2), hydrazine (3a-b) and catalyst (SATA) $(100 \mathrm{mg})$ in $5 \mathrm{~mL}$ ethanol was refluxed for an appropriate time (Table 2). After completion of the reaction (monitored by TLC) the reaction mixture was filtered off to remove the solid catalyst, which was washed with ethanol $(3 \times 15 \mathrm{~mL})$ and ethyl acetate $(2 \times 10 \mathrm{~mL})$ for further

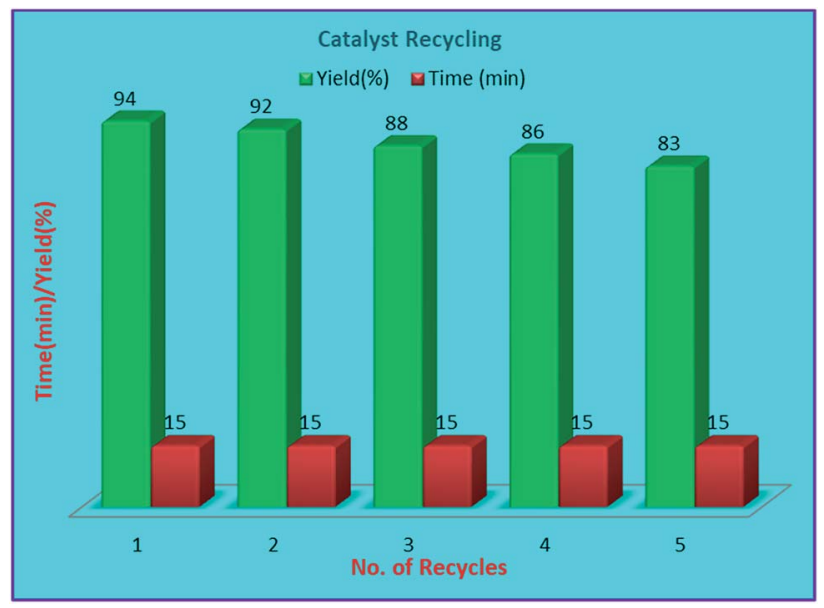

Fig. 7 Recycling data of the catalyst. use. The filtrate was evaporated under reduced pressure to afford product (4). The crude product (4) was purified by recrystallization using ethanol/DMSO as solvent.

\section{Conflicts of interest}

The authors declare no conflict of interest.

\section{Acknowledgements}

Authors provide special thanks to CST, UP, Lucknow, bearing ref. no. CST/SERPD/D-283 (dated, 14 May 2015) for financial support. We acknowledge DRS II (UGC, New Delhi), USIF, AMU, Aligarh, for SEM-EDX, TEM facilities, IIT Guwahati for XRD, BET analyses and SAIF Punjab for providing NMR and Mass spectra.

\section{References}

1 W. F. Hölderich, J. Röseler, G. Heitmann and A. T. Liebens, Catal. Today, 1997, 37, 353-366.

2 A. Corma, Chem. Rev., 1995, 95, 559-614.

3 A. Corma, Chem. Rev., 1997, 97, 2373-2420.

4 S. Namba, N. Hosonuma and T. Yashima, J. Catal., 1981, 72, 16-20.

5 I. Nowak and M. Ziolek, Chem. Rev., 1999, 99, 3603-3624.

6 M. A. Harmer, W. E. Farneth and Q. Sun, J. Am. Chem. Soc., 1996, 118, 7708-7715.

7 J. A. Bootsma and B. H. Shanks, Appl. Catal., A, 2007, 327, 44-51. 
8 (a) I. V Kozhevnikov, Chem. Rev., 1998, 98, 171-198; (b) R. A. Rather and Z. N. Siddiqui, RSC Adv., 2019, 9, 15749-15762. 9 M. E. Davis, Nature, 2002, 417, 813-821.

10 A. Corma and H. García, Chem. Rev., 2003, 103, 4307-4366.

11 A. Zheng, S. Liu and F. Deng, Chem. Rev., 2007, 117, 1247512531.

12 M. Choi, K. Na, J. Kim, Y. Sakamoto, O. Terasaki and R. Ryoo, Nature, 2009, 461, 246-249.

13 X. Zhang, Y. Zhao and Q. H. Yang, J. Catal., 2014, 320, 180188.

14 J. C. Jiang, F. Gándara, Y. B. Zhang, K. Na, O. M. Yaghi and W. G. Klemperer, J. Am. Chem. Soc., 2014, 136, $12844-12847$.

15 M. Hara, T. Yoshida, A. Takagaki, A. Takata, J. N. Kondo, S. Hayashi and K. Domen, Angew. Chem., Int. Ed., 2004, 43, 2955-2958.

16 E. Nikolla, Y. Román-Leshkov, M. Moliner and M. E. Davis, ACS Catal., 2011, 1, 408-410.

17 K. Nakajima, Y. Baba, R. Noma, M. Kitano, J. N. Kondo, S. Hayashi and M. Hara, J. Am. Chem. Soc., 2011, 133, 4224-4227.

18 M. Dusselier, P. V. Wouwe, A. Dewaele, P. A. Jacobs and B. F. Sels, Science, 2015, 349, 78-80.

19 T. Okuhara, Chem. Rev., 2002, 102, 3641-3666.

20 N. Mizuno, K. Yamaguchi and K. Kamata, Catal. Surv. Asia, 2011, 15, 68-79.

21 J. Song, Z.-F. Huang, L. Pan, J.-J. Zou, X. Zhang and L. Wang, ACS Catal., 2015, 5, 6594-6599.

22 B. A. Wasmi, A. A. Al-Amiery, A. A. H. Kadhum and A. B. Mohamad, J. Nanomater., 2014, 7, 2.

23 G. B. Payne and C. W. Smith, J. Org. Chem., 1957, 22, 16821685.

24 F. B. Cao, H. Jiang and G. Hong, Chin. J. Org. Chem., 2005, 25, 96-100.

25 J. Ichihara, Tetrahedron Lett., 2001, 42, 695-697.

26 V. K. Singh and P. T. Deota, Synth. Commun., 1988, 18, 617-624.

27 P. T. Deota, R. Desai and V. B. Valodkar, J. Chem. Res., 1998, 9, 562-563.

28 C. Hui, D. Wei-Lin, G. Ruihua, C. Yong, L. Hexing and F. Kangnian, Appl. Catal., A, 2007, 328, 226-236.

29 A. F. Lee, J. A. Bennett, J. C. Manayil and K. Wilson, Chem. Soc. Rev., 2014, 43, 7887-7916.

30 S. M. Vahdat, S. Khaksar, M. Akbari and S. Baghery, Arabian J. Chem., 2019, 12, 1515-1521.

31 S. K. Kundu and A. Bhaumik, ACS Sustainable Chem. Eng., 2015, 3, 1715-1723.

32 (a) G. M. Ziarani, A. Badiei, N. Lashgari, T. Pourjafar and Z. Farahani, Bulg. Chem. Commun., 2014, 46, 719-723; (b) R. A. Rather and Z. N. Siddiqui, J. Organomet. Chem., 2018, 868, 164-174.

33 G. D. Yadav and J. J. Nair, Microporous Mesoporous Mater., 1999, 33, 1-48.

34 Y. Wang, D. Wang, M. Tan, B. Jiang, J. Zheng, N. Tsubaki and M. Wu, ACS Appl. Mater. Interfaces, 2015, 7, 26767-26775.

35 M. A. Zolfigol, M. Navazeni, M. Yarie and R. Ayazi-Nasrabadi, Can. J. Chem., 2017, 95, 1248-1252.

36 H. Sharghi and O. Asemani, Synth. Commun., 2009, 39, 860-867.
37 J. Kim, D. Lee, C. Park, W. So, M. Jo, T. Ok, J. Kwon, S. Kong, S. Jo and Y. Kim, ACS Med. Chem. Lett., 2012, 3, 678-682.

38 A. D. Cross, Introduction to Practical Infrared Spectroscopy, Butterworth, Washington D.C., 2nd edn, 1964.

39 X. Su, S. Chen and Z. Zhou, Appl. Surf. Sci., 2012, 258, 57125715.

40 N. Ahmed and Z. N. Siddiqui, J. Mol. Catal. A: Chem., 2014, 387, 45-56.

41 P. Kim, Y. Kim, C. Kim, H. Kim, Y. Park, J. H. Lee, I. K. Song and J. Yi, Catal. Lett., 2003, 89, 185-192.

42 H. Hügel, Molecules, 2009, 14, 4936-4972.

43 S. Fustero, A. Simón-Fuentes and J. F. Sanz-Cervera, Org. Prep. Proced. Int., 2009, 41, 253-290.

44 A. R. Kiasat, F. Kazemi and K. Nourbakhsh, Phosphorus, Sulfur, Silicon Relat. Elem., 2004, 179, 569-573.

45 E. Kolvari, N. Koukabi, M. M. Hosseini, M. Vahidian and E. Ghobadi, RSC Adv., 2016, 6, 7419-7425.

46 N. Ahmed and Z. N. Siddiqui, J. Mol. Catal. A: Chem., 2014, 394, 232-243.

47 J. Safari, S. H. Banitaba and S. D. Khalili, J. Mol. Catal. A: Chem., 2011, 335, 46-50.

48 B. S. Kuarm, J. V. Madhav, S. V. Laxmi and B. Rajitha, Synth. Commun., 2012, 42, 1211-1217.

49 R. H. Vekariya and H. D. Patel, $R S C A d v ., 2015,5$, 49006-49030. 50 J. H. Clark, Acc. Chem. Res., 2002, 35, 791-797.

51 V. R. Mudumala, R. R. Chinthaparthi and T. J. Yeon, Tetrahedron, 2014, 70, 3762-3769.

52 R. Konakanchi, S. Kankala and L. R. Kotha, Synth. Commun., 2018, 48, 1777-1785.

53 H. Sachdeva and R. Saro, Sci. World J., 2013, 680671.

54 M. Abaszadeh, M. Seifi and A. Asadipour, Synth. React. Inorg., Met.-Org., Nano-Met. Chem., 2016, 46, 512-517.

55 Green metrics reviews, see: (a) F. Roschangar, R. A. Sheldon and C. H. Senanayake, Green Chem., 2015, 17, 752-768; (b) J. Augé, Green Chem., 2008, 10, 225-231; (c) C. JimenezGonzalez, C. S. Ponder, Q. B. Broxterman and J. B. Manley, Org. Process Res. Dev., 2011, 15, 912-917.

56 (a) X. Zhang, G. Dhawan, A. Muthengi, S. Liu, W. Wang, M. Legris and W. Zhang, Green Chem., 2017, 19, 38513855; (b) P. Wadhwa, T. Kaur and A. Sharma, RSC Adv., 2015, 5, 44353-44360.

57 C. Jiménez-González, D. J. Constable and C. S. Ponder, Chem. Soc. Rev., 2012, 41, 1485-1498.

58 M. M. Khan, S. S. Khan, S. Shareef and S. C. Sahoo, RSC Adv., 2018, 8, 41892-41903.

59 S. Maddila, S. Rana, R. Pagadala, S. Kankala, S. Maddila and S. B. Jonnalagadda, Catal. Commun., 2015, 61, 26-30.

60 J. Rakhtshah, S. Salehzadeh, E. Gowdini, F. Maleki, S. Baghery and M. A. Zolfigol, RSC Adv., 2016, 6, 104875-104885.

61 A. A. Dissanayake and A. L. Odom, Chem. Commun., 2012, 48, 440-442.

62 M. Srivastava, P. Rai and J. Singh, New J. Chem., 2014, 38, 302-307.

63 L. Shen, S. Cao, N. Liu, J. Wu, L. Zhu and X. Qian, Synlett, 2008, 1341-1344.

64 M. B. Yue, T. Xue, W. Q. Jiao, Y. M. Wang and M.-Y. He, Solid State Sci., 2011, 13, 409. 